\title{
Kazimierz Ajdukiewicz's proposal of ethical norms
}

\author{
Stefan Konstańczak
}

\begin{abstract}
Kazimierz Ajdukiewicz is known primarily as a logician and methodologist. Ethics was a side discipline to his scientific research, which he lectured at Lvov University in the 1930s. Assuming that ethics is a philosophical science, he tried to systematise its contemplations according to the scientific principles developed at the LvovWarsaw School of thought. However, in his research he also took into account the philosophical tradition which recognised ethics as one of the chief branches of philosophy. Ajdukiewicz's submission of ethics to the requirements of logic was related to an attempt to analyse its core concepts. Consequently, an outline of the original ethical concept was developed, but never developed into a system.
\end{abstract}

Keywords: Kazimierz Ajdukiewicz, Kazimierz Twardowski, analytic philosophy, the Lvov-Warsaw School, ethics, scientific ethics

\section{Introduction}

The name Kazimierz Ajdukiewicz (1890-1963) is generally associated exclusively with logic, semiotics, epistemology and methodology. With such a perception of his scientific interests, he became a classic representative of the Lvov-Warsaw School; privately he was the son-inlaw of its founder, Kazimierz Twardowski. There is little mention of Ajdukiewicz as a universal philosopher, who also undertook axiological issues, and hence in his scholarly accomplishments there are statements which are strictly ethical in character. However, in light of conducted research, the belief that he did not formulate his own concept of ethics is not confirmed by facts. He could not ignore the power of tradition, which considered ethics to be one of the most important areas of philosophy.

\section{Ajdukiewicz's road to ethics}

Tadeusz Kotarbinski, in his memoirs of Ajdukiewicz, characterised his scientific attitude as follows: "insightful reflection, focused and deep thinking. Ajdukiewicz followed his profession with relish and passion. As one of his former colleagues rightly stated in his speech to the jubilarian, calling him 'a profound thinker'; a mind penetrating the depths" (Kotarbiński, 1964, p. 7).

Unlike most other Polish philosophers Ajdukiewicz, experienced a long route to the scientific world. Already on $1^{\text {st }}$ July 1914 , prior to the outbreak of World War I, he was mobilised into the Austrian army, where he served until $1^{\text {st }}$ October 1918, practically until the end of the war. Then, at his own request, he served in the artillery units of the Polish Army. On $6^{\text {th }}$ November 1918, Kazimierz Twardowski visited Ajdukiewicz (his former doctoral student) in the new unit (Twardowski, 1997, p. 69). Even war did not prevent them from dealing with scientific matters. In his "Diaries" for $22^{\text {nd }}$ September 1918 Kazimierz Twardowski wrote: "Czeżowski and Ajdukiewicz were with me in the morning. We discussed how patriotism can be reconciled with ethics" (Twardowski, 1997, p. 60).

Ajdukiewicz's starting point for formulating his ethical views was to reflect on the issue of human freedom. In 1920, he published an article entitled "Polish Philosophy of Freedom", the result of discussions on patriotism and ethics conducted at Twardowski's house. It was at a time of protest against speculative philosophy, particularly against Kant and his followers. In the article, he acknowledged that in Poland great merits were due, especially to Lukasiewicz 
and Kotarbinski, for creating a new philosophy free from "mists of unproductive speculation". He then stated: "Freedom is a property which Man assigns when he can do something. Man is free when he can call to life, into existence, a certain sphere of objects [...] if we can create something, we can also destroy it and vice versa. [...] this dual capability is a condition of creativity in the broadest sense of these words" (Ajdukiewicz, 1920, p. 3). This was a contextual expression for him, which cannot be attributed to a specific designatum.

The impulse to deal with more specific ethical issues came after reading Kotarbinski's work "Practical Sketches", or more specifically the chapter entitled "The Problem of the Existence of the Future". "The book outlined certain suggestions for the possibility of creating multivalued logic, which predominantly fascinated Ajdukiewicz. Following Kotarbiński, he thus accepted that judgments about the future cannot be true or false, but he used a somewhat unfortunate term for them: "undecided". Importantly, this article unequivocally rejected fatalism and therefore, determinism, in science, because free actions can only be possible, never necessary. This text only had a loose connection with ethics, but it seems it presented the author with some suggestions about the possibility of working out a scientific concept of ethics.

Readings played an important role in shaping Ajdukiewicz's ethical views, and they directed his approach both scientifically and in his private life. An opportunity to reflect about himself came during a stay in Warsaw (1926-1928), when he took up the chair in philosophy at the university. As a professor at the university he took an inauguration oath on $10^{\text {th }}$ December 1925 (Twardowski, 1997, p. 210), but his duties commenced in 1926. His final lectures as a lecturer at Lvov University were delivered on $16^{\text {th }}$ December 1925 . Moving to Warsaw resulted in his appointment to the post of professor at the University of Warsaw, but it also was associated with a renewal of old grudges with former colleagues from the university in Lvov, including Wladyslaw Witwicki and Stanisław Leśniewski (Twardowski, 1997, p. 300). Friction was so great that he never really adapted to Warsaw. He had to show a very high psychological resistance because he had to face, among others, Leśniewski's unjustified charges of plagiarism. Roman Ingarden reminisced about it. "Soon afterwards, a row broke out between Ajdukiewicz and Leśniewski, who accused him of plagiarism. Ajdukiewicz's position in Warsaw became untenable" (Ingarden, 1999, p. 193). There was rivalry amongst Twardowski's students which at times was conducted in an uncivilised manner. However, Ajdukiewicz did not withdraw from his scientific and journalistic work in Warsaw. When he gave his inaugural lecture at the General University of Warsaw, as suggested by the university board, on the basis of his own experience he tried to answer three questions: "1) how I studied philosophy; 2) how I started philosophising; 3) how I would advise others" (Ajdukiewicz, 1927, p. 74). In his lecture he concentrated on answering the second question. Although he stated that many different paths lead to philosophy, he concentrated on presenting his own: "[S]ome are led to it by the need to acquire life's compass which they have lost. They are looking for the answer in philosophy to the question of how to proceed. This question is not about how to behave if one desires to achieve so and so, it is not about indicating the means which guarantee achieving a particular goal; it is about unconditional duty, and ultimately about indicating what our absolute duty is. The need for an answer to this question arises in people, for whom in specific cases, conscience points to fairness and duty, but for whom the voice of their conscience, for whatever reason, is insufficient including those who were religious but have lost the faith.

While teaching religion, conscience is not considered the supreme arbitrator in matters of moral duty which no longer requires sanction of any higher instance. Instead, the binding

\footnotetext{
${ }^{1}$ T. Kotarbiński, Practical sketches. Issues from philosophy of deed, E. Wende i S-ka Bookshop main publisher, Warszawa 1913. The chapter mentioned is included in the book pp.118-150. At the same time Kotarbiński also published an article titled Issues of existence of the future in: "Philosophical Review" (vol. 1 from 1913).
} 
force of the injunctions and prohibitions of conscience is justified by the fact that they are commands and prohibitions from God. Therefore, breaking these commandments is bad; it is a lack of respect for God, an offence against Him which will be punished in this or a future life. Teaching religion thus deprives the voice of conscience of its character of final instance which determines whether something is good or bad. It creates the need to seek out something beyond the voice which is the justification of the voice's judgments and decisions. Thus, Man becomes moulded by such teaching; and after losing his religious faith he may not lose his attitude towards his own conscience but still feel the need to legitimise his judgements and directives. After the loss of religious faith, by not being able to find this legitimacy in divine authority, Man turns to philosophy so that it can provide the voice of his conscience with confirmation or rejection of its verdict" (Ajdukiewicz, 1927, pp. 77-80). Ajdukiewicz couldn't proclaim such a declaration publicly earlier in Lvov, which boasted with its traditionalism, and such declarations would undoubtedly be out of place there. Warsaw though had a strong tradition of free-thinking and religious tolerance.

However, in his lecture, Ajdukiewicz also tried to highlight the benefits of turning to philosophy which come with independence from moral directives and prohibitions that flow directly from religion. "However, not only those for whom teaching religion required legitimacy for remorse, turn to philosophy for life's compass. After all, our own compass has an assessment of what is good and bad, what should be supported, and what to fight and it is not always in agreement. And so, for example, our sense of compassion makes us take pity on human misery and do everything to counter it. On the other hand, our sense of good and evil makes us value human prowess, manifested in both [the] corporal and spiritual needs of man. The $19^{\text {th }}$ Century German philosopher of Polish descent Friedrich Nietzsche called the moral commandments flowing out of pity on human misery "slave morality", whilst the commandments flowing out of worship for human prowess "master morality". The conflict between the two ethics can become a starting point for philosophical inquiries related to solving the dilemma. Also, those who see no conflict in their conscience and feel no need to seek higher sanctions in order to solve it can turn to philosophy in connection with ethical issues. Finally, those can turn to philosophy who desire finding a solution specified in one system and seek the main principles from which all the specific logical judgments follow" (Ajdukiewicz, 1927, pp. 80-82).

Philosophy is therefore indispensable, but not "to justify and systematise one's own moral judgments, but rather to understand morality as a social phenomenon, and to explain the role of morality and society in identifying the purpose they serve in society" ((Ajdukiewicz, 1927, pp. 82-83).

Ajdukiewicz pointed to two other paths leading to philosophy. One was the inner need to build one's own coherent view of the world. The final one that he himself followed was the path of insightful exploration of the essence of what he himself was interested in. He did not impose a path upon his listeners in any way whatsoever, for each of them must make that personal choice. Somewhat surprising were Ajdukiewicz's words related to the teachers to whom he owed most gratitude. He named his mathematics and physics teacher Wincenty Frank, from the III Grammar School in Lvov, the author of popular arithmetic and minerology textbooks for this type of school (Ajdukiewicz, 1927, pp. 9-97).

The explanation as to why he did not choose the first path related to the search for life's compass, which he devoted so much time to, is extremely instructive. "Why not the first path? It so happened that I never felt the need to have my moral judgments sanctioned by some higher authority which my moral sense dictated me. I also realised that however I would like to justify my moral judgments, then without appealing to my moral conscience, even at one point, I will not take one step forward. I realised that there is no logical transition from how it is to how it should be; and that I would not have made any assumption regarding my duties. 
To clarify my thoughts let us consider the simplest example: in order to obtain an end proposal that I should not steal, from: that God commands not to steal, that God is a supernatural being, that breaking his commandment would offend God, I would have to assume for logical order that I should not defend the most venerable being. However, this assumption related to duty cannot be justified other than on the basis of moral premonition. So, I was not looking for the moral compass in philosophy because I had it within me and I realised that if I did not have it within me, philosophy would not help me. Rather, what interested me in ethical issues was the sociology of morality questions than normative ethics" (Ajdukiewicz, 1927, pp. 92-94).

What finally compelled him to pursue the final route was the study of Berkeley, particularly his work A Treatise Concerning the Principles of Human Knowledge. As he later stated, "the Berkeley paradox was a challenge to solve" (Ajdukiewicz, 1927, pp. 99-102). It is thanks to philosophy that Ajdukiewicz became a scientist, and in the context of these considerations it becomes evident why Kotarbiński called him a "profound thinker".

Initially, ethics did not deserve, even for Ajdukiewicz, to be called a scientific discipline. In1923 he claimed that only "[F]ormal logic is, next to empirical psychology, the only philosophical discipline with a remarkably scientific nature" (Ajdukiewicz, 1923, p. 25). It is possible that Ajdukiewicz underwent an evolution of his ideas when he was lecturing ethics at Lvov University, probably not before the 1930s. His lectures, preserved in manuscripts, only begin in 1932. It was a turning point for Ajdukiewicz, as he was starting to cover for Twardowski at Lvov University. He was gaining independence, and his opinions were gaining increasing importance at the university. He was also an informal and unquestioned (also due to kinship) successor to Kazimierz Twardowski at the Jan Kazimierz University in Lvov. He also took over the leadership of the Polish Philosophical Society (PTF). It was a great responsibility, but also an opportunity for him to build his own original philosophical position.

\section{Scientific attempt at ethics}

Ajdukiewicz's lectures on ethics have never been published and have only survived in the form of rough notes and comments kept in the archives of the Polish Academy of Sciences in Warsaw. A sketch of the original concept for adapting ethics to the Learning Science program developed at the Lvov-Warsaw School is contained in a notebook preserved in this archive, as well as notes to lectures on ethics given at Lvov University, i.e. after Kazimierz Twardowski, his father-in-law's, retirement. In the 1930s, it was Ajdukiewicz who was entrusted to lecture in ethics. Ajdukiewicz began his first lecture very originally: "The origin of the word ethics from $\tilde{\eta} \theta 0 \varsigma-$ permanent place of arrival and permanent manner of conduct $=$ custom with a similar meaning to $\varepsilon^{\theta} \theta \mathrm{o} \varsigma=$ habit. Custom - as opposed to habit, something collective, clustered, sanctified tradition. The name ethics encompasses a number of very diverse issues dispersed throughout the history of human thought. These issues are centred around one concept, the concept of «good». Thus, the word «good» has a great variety of meanings. «Good» sometimes means the same as much as «cordial», «benevolent», «indulgent», «human» (good person), «suitable for intended purpose» (good key, good grip $\neq$ but a good horse, still a good vehicle); this can also be extended to as in «good poem», «good drama» meaning «successful». When we say that something was successful we mean someone did something specific for this purpose in order to create something like this. This specific thing is the means to achieve a goal defined as something with particular properties. In addition to these numerous meanings of the word «good», there is one more which is a central concept in ethics, whose characteristic appears as «good deed» and «good character» etc. Ethical considerations should begin with an explanation of this concept i.e. the importance of the meaning of the word «good» in ethics. This explanation would have been 
achieved if we were able to carry out an analysis of the meaning of the term «good». The meaning of the term is the same as the concept. To analyse a concept is just the same as finding two or more other concepts whose combined content $=$ the content of the concept being analysed. For example, square $=$ rectangular and equilateral. The result of such an analysis can be expressed in the sentence A is B, C, which is a content definition. The English philosopher Moore argues that an analysis of the concept of good cannot be performed as in his opinion the concept is a simpliciter. The same cannot be said of the concept yellow. Though it is possible to provide a concept with the same scope as the concept of yellow e.g. "the colour contained in the colour spectrum between orange and green», this is not an analysis of the concept, since the content of the term yellow and the content of the latter do not coincide. It may be possible to find a concept with the same meaning as the concept good, but it will not be its analysis, but a criterion provided which is sufficient and necessary for goodness. To give the secondary concept for good $=$ a criterion sufficient but unnecessary. To give the primary concept for good $=$ a criterion necessary but insufficient.

If clarification of the meaning of the expression 'good man' cannot be carried out by analysing this meaning, then another way is found. Available concepts for its decomposition (analysis) are all the meanings of the terms which have been introduced into the language by the definition of type «A is $\mathrm{B}$ being $\mathrm{C} »$. However, there are only a few words that have been introduced into the language by definitions. Most of the words are learnt using the Berlitz method, i.e. we learn to understand them by getting accustomed to using them in a certain way. For example, we understand the term «yellow» although we have never heard nor can provide the definition «yellow is such and such». We have learned to understand it by observing situations in which others use it in certain contexts and by getting into the habit of using these contexts in similar situations. We observed that in situations characterised by experiencing the impression of a certain tone of colour people say with conviction that this is something yellow. We have learnt to use it in a similar way.

Words we did not introduce by definitions, but which we learn to use by imitating others I call words of habitual meaning. Wanting to clarify the meaning of the habitual word, this can be achieved by pointing out the way this word is used. Particular usage of a certain word is important for its given meaning if someone who does not observe this usage demonstrates that he is not using the word in a given meaning. Who would, for example, at the sight of the colour of a buttercup was not ready to say with conviction this is something yellow, but instead, for example, this is something blue. This way he would demonstrate that he does not associate with the word «yellow» the same meaning as everyone else.

The habitual word is the word «good» and likewise the words «exists» and «true». The usage of the word «exists» is essential. A sentence in a logical sense. Its psychological meaning $=$ judgment in a psychological sense. Its meaning in a logical sense $=$ judgment in a logical sense.

A real judgment can be delivered seriously, make-believe and only considered. The delivered verdict is not a judgment about the judgment, that it is true, but is based on an assertive attitude. In speech, one does not stress whether the judgment is delivered or just considered. Essential for the meaning of correct usage: Whenever I deliver a judgment with a certain wording, I am ready to confidently pronounce about this content the word «true». This is not a declaration of infallibility. Every judgment is about a certain state of affairs found in this judgment. Whenever I deliver a judgment with a certain content I am ready to confidently pronounce the state of affairs stated in this judgment the word «existing».

Essential usage of the meaning for the word good. Regarding the judgment logically one can take up not only an assertive attitude but also many others: an imperative one «let Jan close the door»! an interrogative one «does Jan close the door»? an optative one «for Jan to close the door». There can also be an attitude of approval" (Ajdukiewicz, 1932, pp. 46-49). 
From this lecture from Ajdukiewicz we can conclude that he tried to treat ethics as part of scientific philosophy, which was reflected in the use of both terminology and the way of conducting activities appropriate for the "logistics" of the time. In the following lecture, he continued with his earlier thought:

"Just like the imperatives by adding «let».. the interrogatives by adding «do, does» and the optative by adding «to»

So, the approval attitude we adopt by the addition of:

\section{Characteristics of approving attitude:}

1. The approving evaluative attitude towards the state of things may not go hand in hand with the imperative nor the optative one. «The court should have sentenced me».

2. The approval attitude is categorical and irrevocable. The statement: «a should have been $b$ » is sometimes elliptical, with the default addition «if $\mathrm{a}$ is to be $\mathrm{c}$. You should not smoke cigarettes if you want a healthy heart». But, for example, you should not torment others for your own pleasure.

3. This approval expressed as a duty occurs as if a surrender to authority, however without it, in order to clearly think: HE commands: «do not torment others for your own pleasure». And not as others abide, fearful of punishment because it would be a conditional obligation. Children accustomed to obedience through commands and prohibitions, from their educators learn to grasp things with approval or disapproval, depending on whether they were recommended or forbidden, but this is only at the start of their realisation of order. It is controversial though if any ethical valuation is started this way.

\section{Use of words "good", "just".}

Whenever we are in a position of approval "+" "_"” (evaluative) with respect to something, we are ready to state that it is good (bad) and about the approval itself that it is just (unjust)" (Ajdukiewicz, 1932, pp. 54-55). Thus, Ajdukiewicz tried to proceed in a different way to George Moore who, in his "Principles of Ethics", adopted the position that the concept of "goodness" was indefinable.

In the following lecture, he clarified his position: "[S]o far [it was] about disapproval, i.e. negative approval. Positive approval is associated with it. Whenever we disapprove [of] the state of things we describe it as being forbidden, while those contradictory, we approve as commanded.

$$
\begin{aligned}
& -\mathrm{A} \equiv+(-\mathrm{A}) \\
& +(-\mathrm{A}) \equiv-\mathrm{A}
\end{aligned}
$$

Essential use for the words "good" and "bad":

Whenever someone disapproves of A, the word "bad" is ready to proclaim it. Whenever someone approves of A, the word "good" is ready to proclaim it.

$+\mathrm{A} \rightarrow \mathrm{A} \varepsilon \operatorname{good}=(-\mathrm{A}) \varepsilon$ bad

$-\mathrm{A} \rightarrow \mathrm{A} \varepsilon$ bad $=(-\mathrm{A}) \varepsilon \operatorname{good}$

This is one of the few ways of understanding of the word "good" in ethics, in which " $\varepsilon$ good = duty" $(-\mathrm{A}) \varepsilon$ bad $=\mathrm{A} \varepsilon$ duty" (Ajdukiewicz, 1932, pp. 63-64).

The above-mentioned fragments of Ajdukiewicz's lectures indicate the direction of his thinking in an attempt at bestowing on ethics a scientific characteristic in accordance with the tradition of the Lvov-Warsaw School. This direction was initially begun by Kazimierz Twardowski, according to which there are three types of facts, which are subject to one of the authorities of reasoning: "[F]irstly, assessing things from an ethical standpoint, on the basis of 
conscience; secondly, assessing things from an aesthetic standpoint on the basis of taste, beauty; thirdly, assessing things from a logical standpoint on the basis of reason. These three types of assessment rotate between two extremes: the first between good and evil, the second between beauty and repulsion, the third between truth and falsehood" (Twardowski, 1927, p. 348). This assessment follows the same overriding principle, as Twardowski himself stated as follows: "[I]t is easy to see that the contrasts between truth and falsehood, between beauty and repulsion, between evil and good can be presented as particular types of one general antithesis; it is the opposite of what we call just and what we call unjust" (Twardowski, 1927, p. 348). Twardowski was, therefore, a platonic scholar, who was convinced that reason reaches every truth on the same path. His further reflections on scientific ethics seem to confirm this view. Thus, the task of ethics is not to increase theoretical knowledge, but to identify signposts necessary for the art of life. So, he separated the theoretical aspect from the practical one. The fact that ethics points to goals people should strive towards does not mean that it points to the paths that they should follow. "[S]cientific ethics only has to define and justify the ethical criteria. [...] but by abandoning morality and ethical education, leaving them to other disciplines, ethics is still normative. [...] Because scientific ethics, is not occupied with implementing ethical regulations and by restricting itself to the formulation and justification of ethical criterion, it does not thereby lose the characteristics of normative ethics. For, as in logic, grammar, or as in hygiene, every truth can be expressed in the form of a norm" (Twardowski, 1973, p. 128).

Ajdukiewicz was not only a successor to Twardowski at Lvov University but also his follower. However, concentrating on issues of logic and methodology, he tried to reconcile their assumptions with ethical considerations. This was to lead him straight to radical conventionalism. However, abandoning this viewpoint undoubtedly was related with the failure of these efforts. As a result, he first came closer to utilitarianism, and in principle to naturalism, and later abandoned ethics altogether, without regret, presumably recognising it as a path without prospects. However, traces of this period left a permanent mark on all his creative work, which contributed to subsequent allegations of conventionalism. During a lecture in 1935, in which he was deliberating the problem of moral coercion, he still claimed: "[A] person's decisions are the result of his character and incentives. If two people have the same incentive and one of them performs an immoral act while the other doesn't, then we will acknowledge that the one who performs the immoral act is committing an act more immoral in nature in the domain in which the act lies. One person may be less moral than another in one domain (e.g. sexual), but in a different domain may be more moral. If someone possesses such a character which in a given domain does not lead to immoral actions against those motives that normal living conditions bring, then we bestow on him a normal moral character in the given domain. Thus, moral coercion exists where incentives act on a person in such a way that every person who is less moral than of normal moral character would be made to perform an immoral act. A sound person bears the guilt for deeds committed under moral coercion, but morally the person is not punished for them and is not held responsible" (Ajdukiewicz, 1932-1934, pp. 246-247).

Adjukiewicz's departure from conventionalism began as early as 1934. This is evidenced by his speeches on human values, with an attempt made (to use the language of logic) which at the same time referred to human will, to emotions and desires. Ajdukiewicz showed that they have to relate to two situational contexts, which are expressed by means of phrases: 'someone wants so and so' and 'someone feels inclined so and so'" (Jadacki, 2016, p. 321). Thus, in logic, one talks in the context of de re and de dicte. The first case refers to the objective state (verified), while the second refers to a state about which there is no certainty that it actually took place, because we have no possibility of directly checking whether it was so. Thus, we can only judge with a certain probability that every intelligent person will 
behave in a certain manner in a given situation. Nevertheless, Ajdukiewicz had no doubts that to satisfy scientific rigors the certainty of the first kind is required. "To cultivate science, it is not sufficient to abide by the principles of intellectual honesty, i.e. to allow to be guided in the proclamation of opinion by no other than sincere conviction rooted in deep reflection. It is also necessary to express oneself in an intersubjective language and only proclaim what one is able to establish and justify, being sure of this justification" (Ajdukiewicz, 2016, pp. 157158). Furthermore, referring to the school of philosophy he represented, he noted: "[T]he language of mathematical logic and its proper conceptual apparatus is the basis for our philosophical research. The fact that we restrict ourselves in our philosophical work exclusively to what can be intersubjectively communicated and to what we can justify through a reliable method self-limits the scope of the work. However, there is no place in our research for many problems usually considered as philosophical, and we will even have to exclude certain areas of traditional philosophy from our area of interest, namely, the cases where our methods are insufficient" (Ajdukiewicz, 2016, p. 159).

The problem that was most troublesome for Ajdukiewicz, and thus hindered the development of a coherent concept of ethics, was the issue of a person's free will. This issue was difficult to attain in a coherent theory. Thus, he pointed out: "[T]he problem of free will relates to whether free will is subordinated to the general principle of causality or whether it escapes from its rigour, whether acts of human willpower are merely indirect links in causal chains, having both causes and effects, or do they always just initiate some causal chain with effects, but no cause. A person's dignity seemed to demand recognising that human free will in the aforementioned sense, is somehow discredited by the thought that man is only a component of nature, at the mercy of her forces he cannot resist" (Ajdukiewicz, 1983, p. 168). It was precisely the problem of determining an individual's behaviour through his biological needs that was the subject of his further studies. Human freedom would have to be understood in a completely different way if the mind was dictated by corporeality on how to behave. However, he perceived that human desires could be explained by natural needs whether they be biological or emotional. Despite this, he remained distant from Spencer-style evolutionism, utilitarianism and emotivism. The most common solutions to this problem were solutions binding a person's behaviour to causes which could be explained by means of empirically verifiable indicators. Therefore, in the spirit of Freudian naturalism, he wrote: "[s]atisfying certain natural desires can be undesirable under certain conditions, whether it is due to the good of an individual, or because of the [sic] mandatory moral norms. Under such conditions, it is recommended from the point of view of these goals (the sake of the individual) that the given desire is not satisfied. Indeed, often society does not permit certain natural desires to be met in such a way as to deprive the individual of the physical possibility of satisfying them" Ajdukiewicz, 1938, p. 202). He perceived that ethics exerted a regulatory impact on individuals' lives, limiting them in a sense, but only enough so as not to harm others. One can notice here the significant influence of utilitarianism.

\section{Conclusion}

Ajdukiewicz did not write any work devoted strictly to ethics, although he did appreciate its importance and the need to practice it. However, it was for him an art rather than real science. Nonetheless, these problems were on different occasions the subject of his deliberations, including teaching needs. He certainly did not agree with basing ethics on any authority, as he considered it a non-scientific approach, assuming from the start that there was only one path of pursuing ethical discourse. In this he was also faithful to his principle: "I insist on basing my view of the world on a rational foundation rather than an irrational one, and I do not want to base my view of the world on becoming acquainted with knowledge as many modern philosophers do, but I want to base it on empirics, on experience and practice based on the 
study of reality whose highest achievement are the sciences" (Ajdukiewicz, 1985, p. 191). Ajdukiewicz is hardly ever referred to during ethical debates in contemporary Polish philosophy. He is not even mentioned in the university textbook "Wiedza o etyce" [Ethical basics] (Woleński \& Hartman, 2008) whose co-author is Jan Woleński - an outstanding expert on the Lvov-Warsaw School. In addition, Ajdukiewicz is not treated as an author of the ethics concept in Woleński's latest book "Historico-Philosophical Essays" (Woleński, 2013). In a monograph relating to the Lvov-Warsaw School the only time Wolenski mentions Ajdukiewicz is in reference to his speech "About Justice" delivered in 1939 during a commemoration ceremony on the first anniversary of Kazimierz Twardowski's death. However, this speech was not related to ethics itself but rather was focussed on ethical tools, namely the application of a principle which is generally considered to be just. According to Ajdukiewicz the principle of "equal measure" (Ajdukiewicz, 1939, p. 117) can be an example of such a principle. Such an omission of Ajdukiewicz's philosophy seems to be related to the fact that none of his works on ethics were published and only his unfinished handwritten notes are stored in the archives.

However, it must be stressed that another well-known scholar familiar with the achievements of the Lvov-Warsaw School, Jacek Jadacki, appears to aptly interpret Ajdukiewicz's thoughts on moral issues. In his opinion for Ajdukiewicz, Twardowski's follower, duties and moral norms are related to the applied language since: "if the [sic] sentence $\mathrm{Z}$ uttered by the [sic] person $\mathrm{O}$ expresses judgement on a future act $\mathrm{C}$ by the [sic] person $\mathrm{O}$, a judgement which was uttered 'on the basis of the experienced act of will' of the [sic] person $\mathrm{O}$, and which of the 'germ' from which latter springs the [sic] act $\mathrm{C}$ by the [sic] person $\mathrm{O}$ - this sentence $\mathrm{Z}$ expresses a resolution of the [sic] person O" (Jadacki, 2013, pp. 23-24). Thus, Ajdukiewicz is constantly re-interpreted and rediscovered.

Today, it is only regrettable that he abandoned his research into systemising his own ethical system, since the road he followed was very promising. However, it is worth recalling even the partial results of his efforts, in the hope that they will inspire contemporary ethicists to continue his research.

Stefan Konstańczak - Professor of the ethics section of the Institute of Philosophy at the University of Zielona Gora, Member of the Committee of Philosophical Sciences of the Polish Academy of Sciences

\section{Corresponding author:}

Stefan Konstańczak, Uniwersytet Zielonogórski, Instytut Filozofii, Al. Wojska Polskiego

71A, 65-762 Zielona Góra, Poland

Email: S.Konstanczak@ifil.uz.zgora.pl

\section{References}

AJDUKIEWICZ，K. (1932-1934): Etyka [Ethics, scribed]. In: Materials of Kazimierz Ajdukiewicz III-141. Warszawa: Archives of PAN, no. 110.

AJDUKIEWICZ, K. (1923): Główne kierunki filozofii w wyjątkach z dzieł ich klasycznych przedstawicieli. (Teoria poznania - Logika - Metafizyka) [Main philosophical trends in extracts from the books of their classical representatives: Theory of cognition - Logic Metaphysics]. Lvov: Nakład K.S. Jakubowski.

AJDUKIEWICZ, K. (1927): Jak studiowałem filozofię [How I studied philosophy]. In: Archives of Kazimierz Ajdukiewicz III-141. Warszawa: Archives of PAN, no. 79.

AJDUKIEWICZ, K. (1965): Logika pragmatyczna [Pragmatic Logic], Warszawa: PWN. 
AJDUKIEWICZ, K. (1939): O sprawiedliwości [Regarding Justice]. In: Kultura $i$ Wychowanie, 2, pp. 109-121.

AJDUKIEWICZ, K. (1920): Polska filozofia wolności [Polish philosophy of freedom]. In: Stowo Polskie, 599, p. 3.

AJDUKIEWICZ, K. (1938): Propedeutyka filozofii. Dla liceów ogólnokształcacych [Propedeutics of philosophy: For secondary school use]. Lvov \& Warszawa: KsiążnicaAtlas.

AJDUKIEWICZ, K. (2016): Przemówienie powitalne delegacji polskiej na Międzynarodowym Kongresie Filozofii Naukowej w Sorbonie w roku 1935 [Inaugural Speech to the Polish representatives at the International Congress of Scientific Philosophy in Sorbonne in 1935], trans. by J. Hartman. In: A. Brożek - A. Chybińska (eds.): Fenomen szkoty lwowsko-warszawskiej [Phenomenon of the Lvov-Warsaw School]. Lublin: Academicon, pp. 157-160.

AJDUKIEWICZ, K. (1985): W sprawie artykułu prof. A Schaffa o moich poglądach filozoficznych [Regarding prof. A Schaff's article related to my philosophical views]. In: Ajdukiewicz: Język i poznanie [Language and Cognition], vol. 2. Warszawa: PWN, pp. 155191.

AJDUKIEWICZ, K. (1932): Wybrane zagadnienia z etyki [Chosen ethical issues] In: Materials of Kazimierz Ajdukiewicz III-141. Warszawa: Archives of PAN, no. 110.

AJDUKIEWICZ, K. (1983): Zagadnienia $i$ kierunki filozofii [Issues and directions of philosophy]. Warszawa: Czytelnik.

INGARDEN, R. (1999): Dzieje mojej „kariery uniwersyteckiej” [“My university career“], ed. by R. Jadczak. In: Kwartalnik Filozoficzny, 2, pp. 183-201.

JADACKI, J. J. (2013): Being and Duty: The contribution of 20th-century Polish thinkers to the theory of imperatives and norms. Warszawa: Copernicus Center Press.

JADACKI, J. J. (2016): Struktura logiczna dekalogu [Logical structure of Decalog]. In: S. Janeczek \& A. Starościc (eds.): Etyka [Ethics]. Part I. Koncepcje etyki [The concepts of ethics]. Lublin: Wydawnictwo KUL, pp. 309-324.

KOTARBIŃSKI, T. (1964): O Kazimierzu Ajdukiewiczu [About Kazimierz Ajdukiewicz]. In: Rozprawy logiczne. Ksiegga pamiątkowa ku czci profesora Kazimierza Ajdukiewicza [Logical discourses. Book of Remembrance in honour of professor Kazimierz Ajdukiewicz], Warszawa: PWN, pp. 7-10.

KOTARBIŃSKI, T. (1913): Szkice praktyczne. Zagadnienia z filozofii czynu [Practical sketches: Issues from philosophy of deed]. Warszawa: Skład główny księgarni E. Wende i Ska.

TWARDOWSKI, K. (1927): Etyka wobec teorii ewolucji [Ethics against evolution theory]. In: Twardowski: Rozprawy $i$ artykuty filozoficzne [Philosophical discourses and articles]. Lwów: Księgarnia „Książnica-Atlas”, pp. 343-356.

TWARDOWSKI, K. (1997): Dzienniki [Journals]. Vol: 1. Toruń: Wydawnictwo Adam Marszałek.

TWARDOWSKI, K. (1973): O zadaniach etyki naukowej [Regarding the tasks related to scientific ethics]. In: Etyka, 12, pp. 125-155.

WOLEŃSKI, J. (2013): Historico-Philosophical Essays, vol. 1. Warszawa: Copernicus Center Press.

WOLEŃSKI, J. \& HARTMAN, J. (2008): Wiedza o etyce [Ethical basics]. Warszawa: Wydawnictwa Szkolne PWN. 